\title{
Pharmacokinetic study with computational tools in the medicinal chemistry course
}

\author{
Monique Araújo de Brito \\ Laboratory of Computational Medicinal Chemistry, College of Pharmacy, Fluminense Federal University
}

\begin{abstract}
To improve the teaching-learning process in the Medicinal Chemistry course, new strategies have been incorporated into practical classes of this fundamental discipline of the pharmaceutical curriculum. Many changes and improvements have been made in the area of medicinal chemistry so far, and students should be prepared for these new approaches with the use of technological resources in this field. Practical activities using computational techniques have been directed to the evaluation of chemical and physicochemical properties that affect the pharmacokinetics of drugs. Their objectives were to allow students to know these tools, to learn how to access them, to search for the structures of drugs and to analyze results. To the best of our knowledge, this is the first study in Brazil to demonstrate the use of computational practices in teaching pharmacokinetics. Practical classes using Osiris and Molinspiration were attractive to students, who developed the activities easily and acquired better theoretical knowledge.
\end{abstract}

Uniterms: Medicinal chemistry/teaching-learning process. Pharmacy/education. Cheminformatics. Pharmacokinetics/teaching. Drugs/molecular properties/teaching.

\begin{abstract}
Para melhorar o processo ensino-aprendizagem no curso de Química Medicinal novas estratégias estão sendo incorporadas às aulas práticas desta disciplina fundamental do currículo farmacêutico. Muitas mudanças e melhorias vêm marcando a área de química medicinal e por isso é importante que os alunos sejam colocados nestas novas abordagens na área, com a utilização de recursos tecnológicos. As atividades práticas foram direcionadas para a avaliação dos dados químicos e físico-químicos de fármacos que influenciam as propriedades farmacocinéticas com o auxílio de técnicas computacionais. Os objetivos foram permitir aos alunos conhecer essas ferramentas, saber como acessá-las, procurar as estruturas de fármacos e analisar os resultados. Este é o primeiro estudo publicado no Brasil que apresenta aula prática computacional sobre o tema farmacocinética. As aulas práticas utilizando os servidores Osiris e Molinspiration foram atraentes para os alunos, que desenvolveram as atividades com maior facilidade e sedimentaram o conhecimento teórico adquirido em sala de aula.
\end{abstract}

Unitermos: Química medicinal/processo ensino-aprendizagem. Farmácia/educação. Quimioinformática. Farmacocinética/ensino. Fármacos/propriedades moleculares/ensino.

\section{INTRODUCTION}

To improve the teaching-learning process in the Medicinal Chemistry course, new strategies have been incorporated into practical classes of this fundamental discipline of the pharmaceutical curriculum. Many changes and improvements have marked the area of medicinal chemistry so far, so it is important that students be prepared for these new approaches in this field and for the use of

\footnotetext{
*Correspondence: M. A. Brito. Departamento de Farmácia, Faculdade de Farmácia, Universidade Federal Fluminense - UFF. Rua Mário Viana, 523, Santa Rosa, 24241-000 - Niterói - RJ, Brazil. E-mail: moniquebrito@id.uff.br
}

technological resources. Some of the innovations adapted to the practical lessons of this discipline are the use of molecular modeling methods (Brito, 2011; Andrade et al., 2010; Carvalho et al., 2003) and in silico toxicological evaluation of drugs (Brito et al., 2010). In the Medicinal Chemistry course, lessons cover various topics involving the pharmacokinetic phase. In this sense, classes become easier to understand, and contents, easier to learn when students can search and see practical contextualized results of this rule applied to drugs. Practical classes were offered in coordination with the specific contents of the theoretical lectures. Importantly, the practices were performed using free software that students could access easily and whose 
use other educational institutions might also implement. In this study we demonstrate the use and applications of computational tools that facilitate the learning of Lipinski's rule of five (Ro5) and other pharmacokinetic concepts.

\section{Pharmacokinetic phase}

In the content of the Medicinal Chemistry lessons, there are topics that discuss the pharmaceutical, pharmacokinetic and pharmacodynamic phases. The pharmaceutical phase refers to drug administration routes (enteral or parenteral) and pharmaceutical form (tablet, solution, etc.). The pharmacokinetic phase has four steps: absorption, distribution, metabolism and excretion (ADME). Recently, a phase for the toxicological evaluation of new drug candidates has been incorporated into it, resulting in the ADME-Tox study. Finally, the pharmacodynamic phase deals with drug-macromolecule interactions in structurally specific drugs (Knittel, Zavod, 2008; Thomas, 2003; Korolkovas, Burckhalter, 1988).

\section{The importance of pharmacokinetic properties in drug design}

The process of designing and developing a drug demands investments in Research \& Development (R\&D) of the order of millions of dollars and decades of work by a multidisciplinary team. Estimates indicate a cost of $\$ 800$ million to 1.4 billion and about $15-25$ years from conception to the last phase of clinical research (Davis, Riley, 2004). Thus, to optimize time and costs, new tools have been introduced in the process of evaluating a drug candidate (Tang et al., 2006) and an efficient ADME-Tox study is essential to select promising compounds that have higher odds of not being discarded in the clinical phase. The use of scientific and technological innovations, combining multidisciplinary knowledge with information technology, biotechnology, chemistry and biology, translates into safer and more effective planning (Kadan, Roy, 2007; Geldenhuys et al., 2006).

A major challenge for the development of a drug is the evaluation of its ADME-Tox properties in humans. The analysis of the pharmacokinetic profile of a drug candidate is performed in vitro and in vivo by testing its solubility, absorption, permeability and metabolites, among other parameters (Biswas et al., 2006).

\section{Lipinski's rule of five and other criteria}

Lipophilicity and solubility are the key molecular properties in the absorption of a drug. Pharmacokinetic parameters were first approached theoretically in 1997 when Lipinski and coworkers published the Rule of Five (Ro5) based on the study of properties of 2245 drugs of the World Drug Index (WDI) database approved for Phase II clinical trials (Lipinski et al., 1997). Used to predict the oral bioavailability of a drug, this rule is based on physicochemical characteristics of the tested compounds, including:

(i) $\quad \operatorname{cog} \mathrm{P} \leq 5$;

(ii) Molecular weight (MW) $\leq 500 \mathrm{~g} / \mathrm{mol}$;

(iii) Number of hydrogen bond acceptors (HBA) (sum of $\mathrm{N}$ and $\mathrm{O}$ atoms $) \leq 10$,

(iv) Number of hydrogen bond donors (HBD) (sum of $\mathrm{OH}$ and $\mathrm{NH}$ groups) $\leq 5$.

Other related criteria were added later (Veber et al., 2002):

(v) Number of rotatable bonds (nRotb) $\leq 10$,

(vi) Polar surface area (PSA) $<140 \AA^{2}$.

The simplicity of these criteria to remove outlier molecules made them very easy to implement with the use of specific software. Thus, the Ro5 moved rapidly up in the hierarchy of medicinal chemistry concepts, from being a set of alert criteria in the minds of the medicinal chemists to a commandment engraved in the high altars of do's and don'ts of drug seekers (Abad-Zapatero, 2007).

Drugs that are administered intravenously are exceptions to Ro5 because they do not undergo absorption; the same exception applies to other therapeutic classes that act as substrates for intestinal transporters (Lipinski, 2004).

\section{Computational tools}

In silico approaches are now widely used to study the important parameters that may guide medicinal chemist in evaluating chemical and physicochemical properties of a compound. As these parameters influence pharmacokinetic properties, the main objective of the in silico studies is to avoid unnecessary expenses associated with biological assays of compounds with a high probability of presenting future pharmacokinetic problems, and thus save time and investments (Kadan, Roy, 2007).

The tendency to use software is steadily growing, especially in research centers and universities. Importantly, however, in silico predictions do not replace or disqualify experimental tests, and both should work in partnership with each other. Experimental in vitro and in vivo pharmacokinetics tests are uniquely important for the evaluation of a new drug and, therefore, indispensable.

Understanding that pharmacokinetic properties of compounds are closely associated with their chemical structure, experimental data are stored in computer databases, and a large number of experimental observations are compared with the structural and physicochemical properties. These properties can be used to perform 
computer-assisted in silico screenings (Tetko et al., 2006). The reliability of theoretical models is dependent on the information contained in databases, which have been gradually released by the pharmaceutical industry. These models also undergo challenge tests to determine their degree of confidence (Kadan, Roy, 2007).

Two good examples of free computational tools which help to predict pharmacokinetic properties of drug candidates are Osiris (http://www.organic-chemistry.org/ prog/peo/, Actelion Pharmaceuticals, Ltd.) and Molinspiration (www.molinspiration.com/chemoinformatics. $\mathrm{html}$ ). Several research groups are using pharmacokinetic parameters calculated both in Osiris and Molinspiration to evaluate their molecules of biological interest (Chohan et al., 2010; Jarrahpour et al., 2010; Andrighetti-Frohner et al., 2009; Silva et al., 2009; Mishra et al., 2009; Chen et al., 2009; Cunico et al., 2009; Perez-Pineiro et al., 2009; Vera-DiVaio et al., 2009).

\section{Properties calculated using Osiris}

Osiris can calculate lipophilicity, expressed as clogP, solubility in water, expressed as $\operatorname{logS}$, molecular weight, drug-likeness indices and drug scores. Moreover, the toxicological properties of the compounds may be shown, but this feature was not explored in this practical class. The description of a computational medicinal chemistry class involving in silico toxicology can be found in Brito, 2010.

\section{Properties calculated using Molinspiration}

In Molinspiration, we worked with lipophilicity, expressed as clogP, PSA index, nRotb and HBA/HBD counts. However, this website offers tools to calculate other properties, such as volume and total number of atoms in the molecule.

Analyzing the different approaches, the practical activities on the computer were directed to the evaluation of chemical and physicochemical data that influence the pharmacokinetic properties of a drug using computational techniques. Specific objectives were to allow the students to know these tools, to learn how to access them, to search for the structure of drugs and to analyze results.

\section{MATERIAL AND METHODS}

The drugs chosen belong to three different therapeutic classes:

(i) $\beta$-adrenergic antagonists: propranolol and pindolol (non-selective $\beta_{2}$ ), metoprolol and atenolol (selective $\beta_{2}$ ) (Figure 1);<smiles>CC(C)N=CCC(O)COc1cccc2[nH]ccc12</smiles>

Pindolol<smiles>COCCc1ccc(OCC(O)CNC(C)C)cc1</smiles>

FIGURE 1 - Non-selective $\beta_{2}$ (pindolol and propranolol) and selective $\beta_{2}$ (metoprolol and atenolol) adrenergic antagonists.

(ii) Quinolone antibiotics: nalidixic acid ( $1^{\text {st }}$ generation), ciprofloxacin ( $2^{\text {nd }}$ generation $)$, moxifloxacin ( $3^{\text {rd }}$ generation $)$ and trovafloxacin $\left(4^{\text {th }}\right.$ generation $)$ (Figure 2);

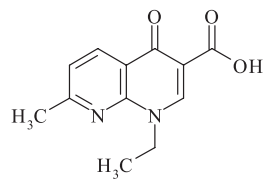

Nalidíxic Acid

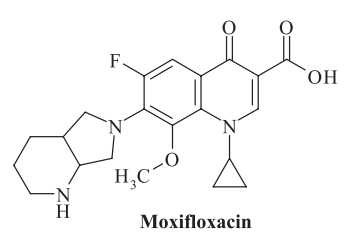

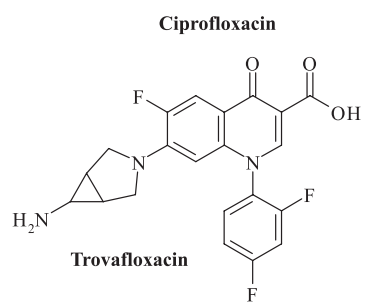

FIGURE 2 - Quinolone antibiotics from first to fourth generation.

(iiii) HMG-CoA reductase inhibitors: simvastatin, fluvastatin, atorvastatin and pitavastatin (Figure 3).

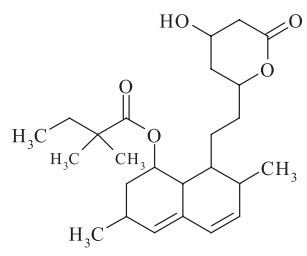

Simvastatin

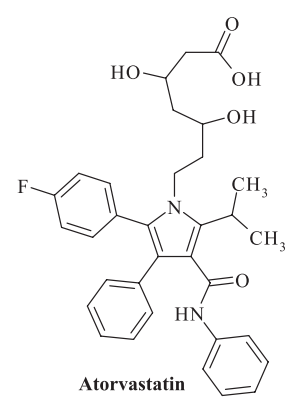

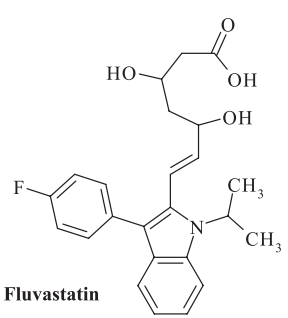

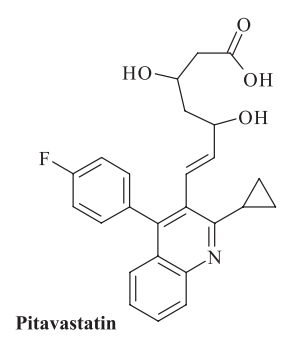

FIGURE 3 - HMG-CoA reductase inhibitors. 
The students performed searches for the chemical structures of drugs, their molecular weight (MW), experimental $\log \mathrm{P}(\mathrm{e} \log \mathrm{P})$, pharmacological receptor and uses of each drug class in the DrugBank (www.drugbank.ca). The DrugBank database is a unique bioinformatics and cheminformatics resource that combines detailed drug data (i.e., chemical, pharmacological and pharmaceutical) with comprehensive drug target information (i.e. sequence, structure, and pathway) (Wishart et al., 2008). The database contains nearly 4,800 drug entries including $>1,350$ FDA-approved small molecule drugs, 123 FDA-approved biotech (protein/peptide) drugs, 71 nutraceuticals and $>3,243$ experimental drugs. Additionally, more than 2,500 non-redundant protein (i.e., drug target) sequences are linked to these FDA-approved drug entries (Wishart et al., 2006).

After that search, they drew each structure on Molinspiration and Osiris servers, where they obtained and visualized the results. After tabulating them to facilitate comparisons, we conducted a discussion in class, and then they wrote their reports.

The practical course of Medicinal Chemistry is taught to students attending the sixth semester of the School of Pharmacy of the Fluminense Federal University (UFF), in addition to theoretical classes.

\section{RESULTS AND DISCUSSION}

One of the topics discussed in the Medicinal Chemistry classes is that high oral bioavailability is an important factor for the optimization of bioactive molecules as therapeutic agents. Passive intestinal absorption (associated with MW and $\log \mathrm{P}$ ), reduced molecular flexibility (measured by nRotb), low PSA or total hydrogen bond counts (HBA and HBD) are important predictors of good oral bioavailability. Lipinski used these molecular properties when formulating his Ro5. This rule is widely used as a filter for drug-like properties, and we used these data to discuss our computational practice (Lipinski et al., 2001).

\section{$\beta$-ADRENERGIC ANTAGONISTS}

$\beta$-adrenergic antagonists are used primarily to control hypertension. The drugs chosen for this practice are chemically classified as aryloxypropanolamines (Griffith, 2008). Propranolol is a drug used for migraine prevention, because, as it is the most lipophilic drug, it can penetrate the blood brain barrier (BBB) more easily. Pindolol and propranolol are non-selective antagonists, binding to both the $\beta_{1}$ to $\beta_{2}$ adrenergic receptors, and are, therefore, contraindicated for patients with asthma. As atenolol and metoprolol are selective for the $\beta_{2}$ adrenoreceptor, they are more safely used in those patients.

Table I shows molecular pharmacokinetic properties calculated for the $\beta$-adrenergic antagonists with Molinspiration and Osiris.

The chemical structures of these compounds (Figure 1) show that propranolol is the most lipophilic drug because of the naphthyl ring. Next is pindolol, which has an indole ring and is more hydrophilic than the naphthyl propranolol; then comes metoprolol, and finally, atenolol. Students noted that the exchange of the functional group ether in metoprolol for the amide in atenolol ensured a greater hydrophilic character to atenolol, probably due to the increased possibility of forming a hydrogen bond between the $-\mathrm{NH}_{2}$ of the amide group and water molecules.

Experimental $\log$ Ps and calculated $\operatorname{logSs}$ (Table I) followed the same order: propranolol $>>$ pindolol $>$ metoprolol $>$ atenolol. Students observed that estimated $\log P$ s also followed the same order both using Osiris and Molinspiration. Compared with elogP, the greatest error in clogP was 0.37 for metoprolol, and the greatest accuracy was 0.03 for propranolol, both calculated using Molinspiration.

The calculated PSA values for the drugs ranged from $41.5 \AA^{2}$ (propranolol) to $84.5 \AA^{2}$ (atenolol). Accord-

TABLE I - Molecular pharmacokinetic properties calculated for the $\beta$-adrenergic antagonists with Molinspiration and Osiris

\begin{tabular}{|c|c|c|c|c|c|c|c|c|c|c|c|}
\hline \multirow{2}{*}{ Drug } & \multirow{2}{*}{ MW } & \multirow{2}{*}{ elogP } & \multicolumn{4}{|c|}{ Osiris } & \multicolumn{5}{|c|}{ Molinspiration } \\
\hline & & & $c \log \mathrm{P}$ & $\log S$ & $\mathrm{DL}$ & DS & $\operatorname{clog} \mathrm{P}$ & PSA & HBD & HBA & nRotb \\
\hline Pindolol & 248 & 1.9 & 1.7 & -2.49 & 7.21 & 0.55 & 1.98 & 57.3 & 3 & 4 & 6 \\
\hline Propranolol & 259 & 3 & 2.81 & -3.57 & 5.73 & 0.67 & 2.96 & 41.5 & 2 & 3 & 6 \\
\hline Metoprolol & 267 & 1.6 & 1.8 & -2.09 & 7.50 & 0.56 & 1.97 & 50.7 & 2 & 4 & 9 \\
\hline Atenolol & 266 & 0.5 & 0.41 & -2.02 & 7.90 & 0.27 & 0.72 & 84.5 & 4 & 5 & 8 \\
\hline
\end{tabular}

Abbreviations: Molecular weight (MW, g/mol), experimental $\log \mathrm{P}(\mathrm{elog} \mathrm{P})$, lipophilicity (clogP), solubility (logS), drug-likeness (DL), drug score (DS), polar surface area (PSA, $\AA^{2}$ ), number of hydrogen bond donor (HBD) and acceptor (HBA) groups, number of rotatable bonds (nRotb) 
ing to Kelder et al., a PSA value less than $60 \AA^{2}$ tends to identify CNS-active compounds (Kelder et al., 1999). In this sense, students were able to see why propranolol is the only drug of the four under study that can be used in migraine prevention, i.e., the only one that has good penetration into the $\mathrm{BBB}$.

A traditional method to evaluate drug-likeness is to check compliance to Lipinski's Ro5, which includes the numbers of hydrophilic groups, molecular weight and hydrophobicity (Lipinski, 2000). The drugs under study showed good results when analyzed using Lipinski's Ro5. The analysis of calculated drug-likeness for these drugs revealed that atenolol achieved the best index, 7.90.

The drug scores attributed by Osiris combine druglikeness, $\operatorname{cog} \mathrm{P}, \log \mathrm{S}, \mathrm{MW}$ and toxicity risks into a value that may then be used to judge the compound's overall potential to qualify as a drug. This value is calculated by multiplying contributions of the individual properties. Table I shows that atenolol received the worst drug score, 0.27 . This probably occurred because atenolol has toxicity risks (mutagenic, irritant and reproductive) according to Osiris (Figure 4). Students conducted searches in medicinal chemistry and pharmacology books and did not find any mention of these toxicity risks of atenolol (Griffith, 2008; Westfall, Westfall, 2006).

The nRotb parameter is a measure of molecular flexibility and a very good descriptor of the oral bioavailability of drugs (Veber et al., 2002). Rotatable bond is defined as any single non-ring bond, bonded to non-terminal heavy atom (i.e., non-hydrogen). For the drugs in Table I, metoprolol had the highest nRotb value (9). Atenolol has eight rotatable bonds, as amide $\mathrm{C}-\mathrm{N}$ bonds are not considered because of their high rotational energy barrier (Veber et al., 2002).

\section{Quinolones}

Quinolones are completely synthetic antibiotics classified into four generations (Mitscher et al., 2008).

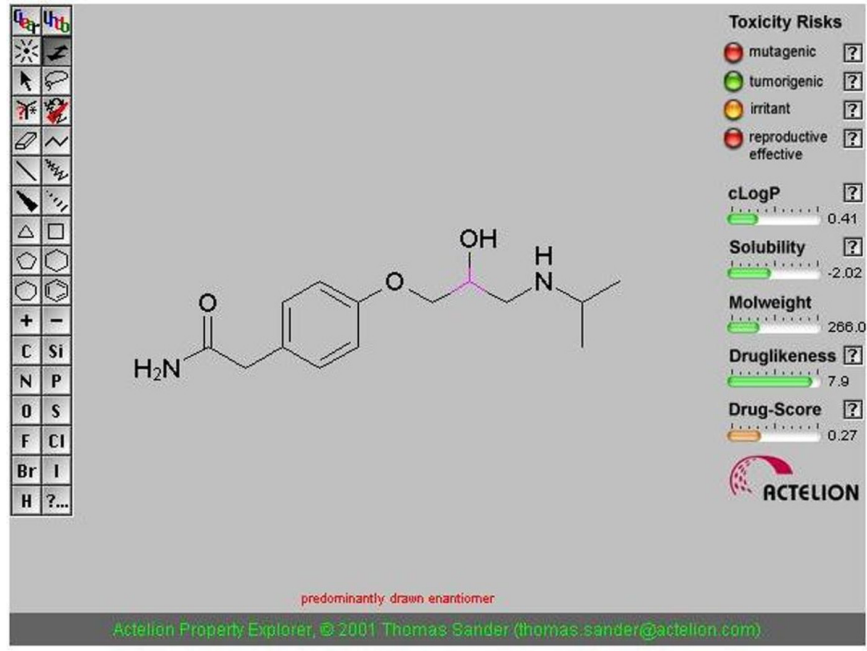

FIGURE 4 - Osiris results for atenolol.

Nalidixic acid belongs to the $1^{\text {st }}$ generation and is used only in uncomplicated infections of the lower urinary tract. The main structural difference from the $1^{\text {st }}$ to the $2^{\text {nd }}$ generation is the fluorine atom at position 6 of the quinolone ring. Ciprofloxacin is one of the main drugs of this generation in terms of sales. The main difference from the $2^{\text {nd }}$ to the $3^{\text {rd }}$ generation, exemplified by moxifloxacin, is the single daily dose, and from the $3^{\text {rd }}$ to the $4^{\text {th }}$ generation (trovafloxacin) the main difference is the activity against anaerobes (Mitscher et al., 2008). The analysis of the structures (Figure 2) reveals that these drugs tend to become more lipophilic from generation to generation.

After analyzing the chemical structures of these compounds (Figure 2) it was easy for students to understand why there is a systematic increase in the experimental $\log$ P (Table II): as the number of hydrocarbon chains increases, so does lipophilicity.

According to Table II there were significant clogP variations for the quinolones in both Osiris and Molinspiration. Compared with Molinspiration, Osiris predicted $\log \mathrm{P}$ with minor errors, except for nalidixic acid, for which

TABLE II - Molecular pharmacokinetics properties calculated for quinolones using Molinspiration and Osiris

\begin{tabular}{|c|c|c|c|c|c|c|c|c|c|c|c|}
\hline \multirow{2}{*}{ Drug } & \multirow{2}{*}{ MW } & \multirow{2}{*}{ elogP } & \multicolumn{4}{|c|}{ Osiris } & \multicolumn{5}{|c|}{ Molinspiration } \\
\hline & & & $\operatorname{clog} \mathrm{P}$ & $\log S$ & $\mathrm{DL}$ & DS & $\operatorname{clog} \mathrm{P}$ & PSA & HBD & HBA & nRotb \\
\hline Nalidixic Ac. & 232 & 2.1 & 0.48 & -2.67 & 1.58 & 0.18 & 0.81 & 72.2 & 1 & 5 & 2 \\
\hline Ciprofloxacin & 331 & 2.3 & 0.13 & -3.32 & 2.07 & 0.39 & -0.70 & 74.5 & 2 & 6 & 3 \\
\hline Moxifloxacin & 401 & 2.9 & 0.58 & -4.23 & 1.6 & 0.32 & 0.39 & 83.8 & 2 & 7 & 4 \\
\hline Trovafloxacin & 416 & 3.7 & 1.51 & -6.03 & 1.37 & 0.39 & 0.80 & 101.4 & 3 & 7 & 3 \\
\hline
\end{tabular}

Abbreviations: Molecular weight (MW, g/mol), experimental $\log \mathrm{P}(\mathrm{e} \log \mathrm{P})$, lipophilicity (clogP), solubility $(\log \mathrm{S})$, drug-likeness (DL), drug score (DS), polar surface area (PSA, $\AA^{2}$ ), number of hydrogen bond donor (HBD) and acceptor (HBA) groups, number of rotatable bonds (nRotb) 
TABLE III - Molecular pharmacokinetics properties calculated for the HMG-CoA reductase inhibitors using Molinspiration and Osiris

\begin{tabular}{|c|c|c|c|c|c|c|c|c|c|c|c|}
\hline \multirow{2}{*}{ Drug } & \multirow{2}{*}{ MW } & \multirow{2}{*}{ elogP } & \multicolumn{4}{|c|}{ Osiris } & \multicolumn{5}{|c|}{ Molinspiration } \\
\hline & & & $\operatorname{clog} \mathrm{P}$ & $\log S$ & $\mathrm{DL}$ & DS & $\log \mathrm{P}$ & PSA & HBD & HBA & nRotb \\
\hline Simvastatin & 418 & 4.7 & 4.79 & -4.75 & 0.67 & 0.43 & 4.76 & 72.83 & 1 & 5 & 7 \\
\hline Fluvastatin & 411 & 4.5 & 4.32 & -4.68 & -0.05 & 0.43 & 4.13 & 82.69 & 3 & 5 & 8 \\
\hline Atorvastatin & 558 & 5.7 & 5.55 & -6.92 & 1.03 & 0.22 & 5.25 & 111.78 & 4 & 7 & 12 \\
\hline Pitavastatin & 421 & - & 4.59 & -6.37 & 1.08 & 0.36 & 3.91 & 90.64 & 3 & 5 & 8 \\
\hline
\end{tabular}

Abbreviations: Molecular weight (MW, g/mol), experimental $\log \mathrm{P}($ elogP), lipophilicity $(\operatorname{cog} \mathrm{P})$, solubility (logS), drug-likeness (DL), drug score (DS), polar surface area (PSA, $\AA^{2}$ ), number of hydrogen bond donor (HBD) and acceptor (HBA) groups, number of rotatable bonds (nRotb)

there was an error of $c a$. 0.6. The highest accuracy was predicted by Molinspiration for the nalidixic acid, with an error of $c a$. 0.3 .

The analysis according to Lipinski's Ro5 revealed that all compounds showed good results in relation to MW, $\log \mathrm{P}, \mathrm{HBD}$ and HBA groups. Compared with previous series, these drugs have greater MW and more HBA groups.

The quinolone drugs showed worse drug-likeness values and drug scores than the drugs studied previously.

The PSA values calculated for the drugs ranged from $72.2 \AA^{2}$ (nalidixic acid) to $101.4 \AA^{2}$ (trovafloxacin).

For these drugs, nRotb values were well below the previous series, indicating low flexibility.

\section{HMG-CoA reductase inhibitors}

These drugs are members of the class known as statins. They inhibit the catalytic site of HMG-CoA reductase, the rate-determining enzyme located in hepatic tissue that produces mevalonate, a small molecule used in the synthesis of cholesterol and other mevalonate derivatives (Harrold, 2008). This lowers the amount of cholesterol produced, which in turn lowers the total amount of LDL cholesterol. They are useful in the treatment of hiperlipidemia.

These drugs have greater structural variability than those of other classes and the highest lipophilicity, expressed by their experimental and calculated $\log P s$ (Table III). The most lipophilic drug is atorvastatin (with elogP=5.7). In fact, atorvastatin has four aromatic rings, one more than the other drugs.

The analysis of $\log P$ revealed that both servers calculated the simvastatin lipophilicity (4.7) with no error, but in general Osiris was more accurate in the calculations for fluvastatin and atorvastatin, with an error of 0.2 for both. The $\log S$ values were the largest when compared with the other series. The highest value was -6.92 for atorvastatin.

All compounds showed good results in the analysis of Lipinski's Ro5 for MW, $\log \mathrm{P}$, and HBA/HBD counts, except atorvastatin clogP, which was greater than 5 (5.7), and MW, greater than $500 \mathrm{~g} / \mathrm{mol}(558 \mathrm{~g} / \mathrm{mol})$, the limits of Lipinski's Ro5. Moreover, the nRotb value (12) shows high flexibility for this drug. These results showed that atorvastatin violates two of the four criteria of the Ro5 and nRotb, which indicates problems with oral bioavailability.

Atorvastatin was launched by the Warner Lambert Co. (acquired by Pfizer) under the trade name Lipitor ${ }^{\mathrm{TM}}$ in 1997. Since 2001, Lipitor has been the leading product in global pharmaceutical sales, reaching $\$ 13.6$ billion in 2006 (Hajkova et al., 2008). It was the first drug to reach the annual sales of $\$ 10$ billion in the US and is currently the top selling pharmaceutical product globally.

Our findings show that the Ro5 criteria are very useful in selecting better compounds in chemolibraries, but they must be used carefully and cautiously to avoid the possible exclusion of promising compounds.

\section{CONCLUSIONS}

Computational classes using Osiris and Molinspiration were attractive to students, who developed the activities with ease and acquired better theoretical knowledge. The reports handed in by students showed good sedimentation and maturation of knowledge on the topic of the classes. In the informal internal evaluation of the practices, all students said that the use of in silico tools contributed greatly to their understanding of the content. Of the difficulties encountered, the most frequent was to understand the entirely new concept of PSA. The lessons certainly contributed to a better teaching-learning relationship.

Both programs have advantages and disadvantages. The advantage of Molinspiration is to provide more data (polar surface area, hydrogen bond donor and hydrogen bond acceptor) than Osiris. The advantage of Osiris is to provide values for drug-likeness and drug scores. Both are free software easily accessed by any student. 
However, we should be very cautious about relying too heavily on the Ro5 criteria, for two reasons: first, there are examples of successful drugs (i.e., atorvastatin) that are notable violators of the Ro5; and second, we should never underestimate the impact of highly improbable events on our theories and preconceived notions. This rule is very useful to select better compounds in chemolibraries, but it must be used carefully and according to specific criteria to avoid the possible exclusion of promising compounds.

Drug-likeness indices are inherently limited tools. Drug-likeness can be estimated for any molecule, and does not evaluate the actual specific effect of a drug (biological activity). Furthermore, first-pass metabolism, which is biochemically selective, may destroy the pharmacological activity of a compound despite its good drug-likeness.

Lipinski's rule of five has not been included in many of the medicinal chemistry books yet, which raises the possibility of creating a contextualized computational practice that may enhance teaching and learning.

\section{ACKNOWLEDGEMENTS}

I gratefully acknowledge the financial support provided by Pró-Reitoria de Pesquisa, Pós-Graduação e Inovação (PROPPi) of Universidade Federal Fluminense.

\section{REFERENCES}

ABAD-ZAPATERO, C. A Sorcerer's apprentice and the rule of five: from rule-of-thumb to commandment and beyond. Drug Disc. Today, v.12, p.995-998, 2007.

AJAY; WALTERS, W. P.; MURCKO, M. A. Can we learn to distinguish between "drug-like" and "nondrug-like" molecules? J. Med. Chem., v.41, p.3314-3324, 1998.

ANDRADE, C.H.; TROSSINI, G.H.G.; FERREIRA, E.I. Modelagem molecular no ensino de química farmacêutica. Rev. Eletr. Farm., v.7, p.1-23, 2010.

ANDRIGHETTI-FROHNER, C.R.; DE OLIVEIRA, K.N.; GASPAR-SILVA, D.; PACHECO, L.K.; JOUSSEF, A.C.; STEINDEL, M.; SIMOES, C.M.O.; DE SOUZA, A.M.T.; MAGALHAES, U.O.; AFONSO, I.F.; RODRIGUES, C.R.; NUNES, R.J.; CASTRO, H.C. Synthesis, biological evaluation and SAR of sulfonamide 4-methoxychalcone derivatives with potential antileishmanial activity. Eur. $J$. Med. Chem., v.44, p.373-383, 2009.
BISWAS, D.; ROY, S.; SEN, S. A Simple Approach for Indexing the Oral Druglikeness of a Compound: Discriminating Druglike Compounds from Nondruglike Ones. J. Chem. Inf. Model., v.46, p.1394-1401, 2006.

BLAKE, J. F. Chemoinformatics - predicting the physicochemical properties of 'druglike' molecules. Curr. Opin. Biotech., v.11, p.104-107, 2000.

BRITO, M. A. Explicando resistência a fármacos: o caso da transcriptase reversa do HIV-1. Rev. Eletr. Farm., v.8, p.88-107, 2011.

BRITO, M. A. Avaliação de propriedades toxicológicas de fármacos in silico no curso experimental de química medicinal. Rev. Eletr. Farm., v.7, p.22-29, 2010.

BRÜSTLE, M.; BECK, B.; SCHINDLER, T.; KING, W.; MITCHELL, T.; CLARK, T. Descriptors, physical properties, and drug-likeness. J. Med. Chem., v.45, p.3345$3355,2002$.

CARVALHO, I.; PUPO, M.T.; BORGES, A.D.L.; BERNARDES, L.S.C. Introdução a modelagem molecular de fármacos no curso experimental de química farmacêutica. Quim. Nova, v.26, p.428-438, 2003.

CHEN, Y.; ZHU, Q.J.; PAN, J.; YANG, Y.; WU, X.P. A prediction model for blood-brain barrier permeation and analysis on its parameter biologically. Comp. Meth. Progr. Biomed., v.95, p.280-285, 2009.

CHOHAN, Z.H.; YOUSSOUFI, M.H.; JARRAHPOUR, A.; BEN HADDA, T. Identification of antibacterial and antifungal pharmacophore sites for potent bacteria and fungi inhibition: indolenyl sulfonamide derivatives. Eur. J. Med. Chem., v.45, p.1189-99, 2010.

CLARK, D. E.; PICKETT, S. D. Computational methods for the prediction of drug-likeness. Drug Disc. Today, v.5, p.49-58, 2000.

CUNICO, W.; GOMES, C.R.B.; FACCHINETTI, V.; MORETH, M.; PENIDO, C.; HENRIQUES, M.G.M.O.; VAROTTI, F.P.; KRETTLI, L.G.; KRETTLI, A.U.; DA SILVA, F.S. Synthesis, antimalarial evaluation and molecular modeling studies of hydroxyethylpiperazines, potential aspartyl protease inhibitors. Eur. J. Med. Chem., v.44, p.3816-3822, 2009. 
DA SILVA, F.D.; DE SOUZA, M.C.B.V.; FRUGULHETTI, I.I.P.; CASTRO, H.C.; SOUZA, S.L.D.; DE SOUZA, T.M.L.; RODRIGUES, D.Q.; SOUZA, A.M.T.; ABREU, P.A.; PASSAMANI, F.; RODRIGUES, C.R.; FERREIRA, V.F. Synthesis, HIV-RT inhibitory activity and SAR of 1-benzyl-1H-1,2,3-triazole derivatives of carbohydrates. Eur. J. Med. Chem., v.44, p.373-383, 2009.

DAVIS, A. M.; RILEY, R. J. Predictive ADMET studies, the challenges and the opportunities. Curr. Op. Chem. Biol., v.8, p.378-386, 2004.

ERTL, P.; ROHDE, B.; SELZER, P. Fast calculation of molecular polar surface area as a sum of fragment-based contributions and its application to the prediction of drug transport properties. J.Med.Chem., v.43, p.3714-3717, 2000.

GELDENHUYS, W. J.; GAASCH, K. E.; WATSON, M.; ALLEN, D. D.; VAN DER SCHYF, C. J. Optimizing the use of open-source software applications in drug discovery. Drug Disc. Today, v.11, p.127-132, 2006.

GRIFFITH, R.K. Adrenergic receptors and drugs affecting adrenergic neurotransmission. In: LEMKE, T.L.; WILLIAMS, D.A., (Eds.). Foye's principles of medicinal chemistry. 6.ed. New York: Lippincott Williams \& Wilkins, 2008. p.392-416.

HAJKOVA, M.; KRATOCHVILA, B.; RADL, S. Atorvastatin - The world's best selling drug. Chem. Listy, v.102, p.3-14, 2008.

HARROLD, M. Antihyperlipoproteinemics and inhibitors of cholesterol biosynthesis. In: LEMKE, T.L.; WILLIAMS, D.A., (Eds.). Foye's principles of medicinal chemistry. 6.ed. New York: Lippincott Williams \& Wilkins, 2008. p. 1375.

JARRAHPOUR, A.; MOTAMEDIFAR, M.; ZAREI, M.; YOUSSOUFI, M.H; MIMOUNI, M.; CHOHAN, Z.H.; BEN HADDA, T. Petra, Osiris, and Molinspiration together as a guide in drug design: predictions and correlation structure/antibacterial activity relationships of new n-sulfonyl monocyclic $\beta$-lactams. Phosphorus, Sulfur Silicon Relat. Elem., v.185, p.1563-5325, 2010.

KADAN, R. U.; ROY, N. Recent trends in drug likeness prediction: a comprehensive review of in silico methods. Ind. J. Pharm. Sci., v.69, p.609-615, 2007.
KELDER, J.; GROOTENHUIS, P.D.; BAYADA, D.M.; DELBRESSINE, L.P.; PLOEMEN, J.P. Polar molecular surface as a dominating determinant for oral absorption and brain penetration of drugs. Pharm. Res., v.16, p.1514$1519,1999$.

KNITTEL, J.J.; ZAVOD, R.M. Drug design and relationship of functional groups to pharmacologic activity. In: LEMKE, T.L.; WILLIAMS, D.A., (Eds.). Foye's principles of medicinal chemistry. 6.ed. New York: Lippincott Williams \& Wilkins, 2008. p.26-53.

KOROLKOVAS, A; BURCKHALTER, J.H. Química Farmacêutica. São Paulo: Ed. Guanabara Koogan, 1988. $783 \mathrm{p}$.

LIPINSKI, C. A. Lead- and drug-like compounds: the rule-offive revolution. Drug Disc. Today: Technol., v.1, p.337-341, 2004.

LIPINSKI, C. A.; LOMBARDO, F.; DOMINY, B. W.; FEENEY, P. J. Experimental and computational approaches to estimate solubility and permeability in drug discovery and development settings. Adv. Drug Deliv. Rev., v.46, p.3-26, 2001.

LIPINSKI, C. A. Drug-like properties and the causes of poor solubility and poor permeability. J. Pharmacol. Toxicol. Methods, v.44, p.235-249, 2000.

LIPINSKI, C.A.; LOMBARDO, F.; DOMINY, B. W.; FEENEY, P. J. Experimental and computational approaches to estimate solubility and permeability in drug discovery and development settings. Adv. Drug Deliv. Rev., v.23, p.3-25, 1997.

MITSCHER, L.A.; LEMKE, T.L.; GENTRY, E.J. Antibiotics and antimicrobial agents. In: LEMKE, T.L.; WILLIAMS, D.A., (Eds.). Foye's principles of medicinal chemistry. 6.ed. New York: Lippincott Williams \& Wilkins, 2008. p.1028-1083.

MOLINSPIRATION Property Calculation Service. Available at: <www.molinspiration.com/chemoinformatics.html > . Accessed on: 28 Apr. 2011.

MUEGGE, I.; HEALD, S. L.; BRITELLI, D. Simple selection criteria for drug-like chemical matter. J. Med. Chem., v.44, p.1841-1846, 2001. 
OPREA, T. I.; DAVIS, A. M.; TEAGUE, S. J.; LEESON, P. D. Is there a difference between leads and drugs? A historical perspective. J. Chem. Inf. Comput. Sci., v.41, p.1308-1315, 2001 .

PEREZ-PINEIRO, R.; BURGOS, R.; JONES, A.; ANDREW, D.C.;RODRIGUEZ, L.C.; SUAREZ, H.; FAIRLAMB, M.; WISHART, A.H.; DAVID, S. Development of a novel virtual screening cascade protocol to identify potential trypanothione reductase inhibitors. J. Med. Chem., v.52, p.1670-1679, 2009.

PROUDFOOT, J. R. Drugs, leads, and drug-likeness: an analysis of some recently launched drugs. Bioorg. Med. Chem. Lett., v.12, p.1647-1650, 2002.

SINGH, M.H.; LAHIRI, N.; KRISHNA, T.M. A comparative study on the molecular descriptors for predicting druglikeness of small molecules. Bioinformation, v.3, p.384386, 2009.

TANG, Y.; ZHU, W.; CHEN, K.; JIANG, H. New technologies in computer-aided drug design: toward target identification and new chemical entity discovery. Drug Disc. Today Techn., v.3, p.307-313, 2006.

TETKO, I. V.; BRUNEAU, P.; MEWES, H.; ROHRER, D. C.; PODA, G. I. Can we estimate the accuracy of ADMET predictions? Drug Disc. Today, v.11, p.700-707, 2006.

THOMAS G. Fundamentals of Medicinal Chemistry. London: John Wiley \& Sons, 2003. 410 p.

VEBER, D. F.; JOHNSON, S. R.; CHENG, H-Y.; SMITH, B.R.;WARD, K. W.; KOPPLE, K. D. Molecular properties that influence the oral bioavailability of drug candidates. $J$. Med. Chem., v.45, p.2615-2623, 2002.
VEBER, D.F.; JOHNSON, S.R.; CHENG, H.-Y.; SMITH, B.R.; WARD, K.W.; KOPPLE, K.D. Molecular properties that influence the oral bioavailability of drug candidates. J. Med. Chem., v.45, p.2615-2623, 2002.

VERA-DIVAIO, M.A.F.; FREITAS, A.C.C.; CASTRO, H.C.; DE ALBUQUERQUE, S. C., RODRIGUES, C.R.; ALBUQUERQUE, M.G.; MARTINS, R.C.A.; HENRIQUES, M.G.M.O.; DIAS, L.R.S. Synthesis, antichagasic in vitro evaluation, cytotoxicity assays, molecular modeling and SAR/QSAR studies of a 2-phenyl3-(1-phenyl-1H-pyrazol-4-yl)-acrylic acid benzylidenecarbohydrazide series. Bioorg. Med. Chem., v.17, p.295303, 2009.

WESSEL, M. D.; JURS, P. C.; TOLAN, J. W.; MUSKAL, S. M. Prediction of human intestinal absorption of drug compounds from molecular structure. J. Chem. Inf. Comput. Sci., v.38, p.726-735, 1998.

WESTFALL, T.C.; WESTFALL, D.P. Agonistas e antagonistas adrenérgicos. In: Goodman \& Gilman. As Bases Farmacológicas da Terapêutica. 11.ed. Rio de Janeiro: McGrawHill, 2006. p.961-1002.

WISHART, D.S.; KNOX, C.; GUO, A.C.; CHENG, D.; SHRIVASTAVA, S.; TZUR, D.; GAUTAM, B.; HASSANALI, M. DrugBank: a knowledgebase for drugs, drug actions and drug targets. Nucleic Acids Res., v.36, p.901-906, 2008.

WISHART, D.S.; KNOX, C.; GUO, A.C.; SHRIVASTAVA, S.; HASSANALI, M.; STOTHARD, P.; CHANG, Z.; WOOLSEY, J. DrugBank: a comprehensive resource for in silico drug discovery and exploration. Nucl. Acids Res., v.34, p.668-672, 2006.

Received for publication on $21^{\text {st }}$ April 2011 Accepted for publication on $04^{\text {th }}$ October 2011 
